\title{
Визначення важкості неглекту як передумови побудови втручання фізичного терапевта
}

\author{
УДК: 616.831-005-036.11-036.868-08 \\ О. А. Дуло, Ю. М. Дідо
}

Ужгородський національний університет, Ужгород, Україна

\begin{abstract}
Анотація. Мета. Визначити та дослідити особливості порушення функцій у осіб з правопівкульним ішемічним інсультом, ускладненим неглектом. Методи і організація дослідження. Аналіз науково-методичної літератури, синтез та узагальнення; контент-аналіз медичної документації (результатів об'єктивних досліджень, протоколів МРТ-досліджень головного мозку); оцінювання когнітивних функцій за шкалою МоСА, тест викреслювання зірок; тест поділу ліній навпіл. Отримані результати були опрацьовані адекватними методами математичної статистики. У дослідження були включені пацієнти з діагнозом гостре порушення мозкового кровообігу у правій гемісфері головного мозку за ішемічним типом, ускладненим неглектом. Всього 45 пацієнтів, із них 22 жінки та 23 чоловіки. Середній вік пацієнтів 68,4 4 7,73 року. Результати. Для діагностики та оцінки використовували алгоритм «SOAP». Результати за тестами на викреслювання зірок становили 33 \%, а поділ ліній навпіл - 46,1 \% від норми. Внаслідок неглекту у пацієнтів за шкалою МоСА було виявлено проблеми із зорово-конструктивними виконавчими навичками, пам'ятью, увагою, абстракцією та орієнтацією. Загальний бал - $13(9 ; 18) 330$ можливих. Висновки. Синдром неглекту це порушення сприйняття простору і схеми свого тіла, виражений в ігноруванні половини тіла і/чи простору з боку, протилежного ураженій півкулі головного мозку, а також інформації, що надходить з цього боку. Результати визначення важкості неглекту мають виявляти цілі фізичної терапії та ерготерапії осіб, які перенесли інсульт.

Ключові слова: інсульт, неглект, діагностика, фізична терапія, ерготерапія.
\end{abstract}

Determination of the severity of the neglect as a prerequisite for designing a physical therapist intervention

O. A. Dulo, I. M. Dido

Uzhgorod National University, Uzhgorod, Ukraine

Abstract. Objective. To determine and study the features of function impairement in persons with right-sided ischemic stroke complicated by neglect. Methods and organization of study: analysis of scientific and methodological literature, synthesis and generalization; content analysis of medical records (results of objective studies, protocols of brain MRI studies); cognitive screening according to MoCA scale, the Star Cancellation Test, the Line Bisection Test. The obtained results were processed by adequate methods of mathematical statistics. The study included patients with a diagnosis of acute cerebral circulation in the right hemisphere of the brain according to an ischemic type complicated by neglect. A total of 45 patients, including 22 women and 23 men, participated in the study. The average age of the patients was $68.4 \pm 7.73$ years. Results. The SOAP algorithm (protocol) was used for diagnosis and evaluation. The Star Cancellation Test results were $33 \%$ and The Line Bisection Test results were $46.1 \%$ of the norm. Due to neglect, in patients according to MoCA scale were revealed problems with visual-constructive performance skills, memory, attention, abstraction, and orientation. The total score constituted $13(9 ; 18)$ out of 30 possible. Conclusions. Neglect syndrome is a disorder of perception of space and scheme of own body, expressed in ignoring half of the body and/or space on the side opposite to the affected hemisphere of the brain, as well as information coming from that side. The results of determining the severity of the neglect should determine the goals of physical therapy and ergotherapy of the persons who have suffered from stroke.

Keywords: stroke, neglect, diagnosis, physical therapy, ergotherapy. 
Постановка проблеми. В Європі інсульт залишається однією 3 головних причин смерті та функціональної неспроможності. Прогнози показують, що за умови використання підходу «все як завжди» тягар інсульту не зменшиться в наступні десятиліття [16].

Згідно з оцінками Глобального тягаря хвороб (Global Burden of Disease), в Україні у 2016 р. виникло понад 200 тис. інсультів і понад 85 тис. осіб померли від інсульту [8,10]. У близько $35 \%$ осіб, які перенесли інсульт, залишається функціональна неспроможність, що призводить до більш ніж одного порушення, яке може впливати на повсякденну діяльність [16]. Внаслідок інсульту відбувається ушкодження головного мозку, що спричиняє раптову втрату певних функцій, які забезпечувала уражена частина мозку [1].

Інсульт викликає моторні та когнітивні десріцити, що знижує незалежність у діяльності щоденного життя. Когнітивні порушення після інсульту $\epsilon$ поширеним, але залишаються мало діагностованими і ускладнюють прогноз відновлення. Деякі форми когнітивних порушень спостерігаються у 40-70\% пацієнтів [1, 6]. Серед них різні види апраксії, синдром неглекту та ін.

Як свідчить світова практика, найкращі результати лікування інсульту можуть бути досягнуті при перебуванні пацієнта у спеціалізованому інсультному відділенні, яке розташоване у багатопрофрільній лікарні і дозволяє поєднати допомогу у гострому періоді захворювання з ранньою і повноцінною реабілітацією [2]. Реабілітація була визначена ВООЗ як «комплекс заходів, що допомагають особам, які відчувають або можуть відчувати фрункціональну неспроможність, досягати і підтримувати оптимальне фрункціонування у взаємодії з навколишнім середовищем» [18]. Дуже важливо дати можливість особам з функціональними обмеженнями залишатися у своєму помешканні або у спільноті, чи повертатися туди і жити незалежно від сторонньої допомоги.

Тому вкрай важливою $€$ розробка заходів фрізичної терапії та ерготерапії з метою цілеспрямовано впливати на незалежність у повсякденному житті, на покращення якості життя та підвищення функціональних можливостей осіб з інсультом.

Зв'язок роботи 3 науковими програмами або практичними завданнями. Роботу виконано відповідно до наукової теми кафредри фрізичної терапії ДВНЗ «Ужгородський національний університет» на 2016-2020рр. «Відновлення психофрізичного потенціалу організму осіб різного віку і статі, які мають відхилення у стані здоров'я, із застосуванням новітніх реабілітаційних технологій» (номер державної реєстрації 0116U003326).
Мета дослідження: визначити та дослідити особливості порушення функцій у осіб з правопівкульним ішемічним інсультом, ускладненим неглектом.

Методи і організація дослідження: аналіз науково-методичної літератури, синтез та узагальнення; контент-аналіз медичної документації (результатів об'єктивних досліджень, протоколів МРТ-досліджень головного мозку); оцінювання когнітивних функцій за шкалою МоСА; тест викреслювання зірок (Star Concellation Test); тест поділу ліній навпіл (Line Bisection Test). Отримані результати були опрацьовані адекватними методами математичної статистики.

У дослідження були включені пацієнти з діагнозом гостре порушення мозкового кровообігу у правій гемісфрері головного мозку за ішемічним типом, ускладненим неглектом. Всього 45 пацієнтів, 3 них 22 жінки та 23 чоловіки. Середній вік пацієнтів з правопівкульним ішемічним інсультом, ускладненим неглектом, що брали участь у дослідженні, становив 68,4 \pm 7,73 року. За локалізацією інсульту були відібрані пацієнти виключно з гострим порушенням мозкового кровообігу у басейні правої середньої мозкової артерії.

Результати дослідження та їх обговорення. Відновне лікування після порушення мозкового кровообігу $\epsilon$ об'єктом уваги широкого кола фрахівців, які займаються з даною категорією хворих на різних етапах реабілітаційного процесу і вирішують завдання психічної і фрізичної активізації, соціальної і трудової адаптації [12].

Однією з найважливіших і при цьому невирішених проблем під час проведення реабілітації пацієнтів після інсульту $\epsilon$ ерготерапія хворих із синдромом неглекту. На думку ряду дослідників, синдром ігнорування $\epsilon$ одним із важливих фракторів, які стримують відновлення неврологічних фрункцій $[3,5,17]$. Просторове ігнорування при синдромі неглекту асоціюється 3 мінімальним відновленням рухових, чутливих, координаційних та когнітивних фрункцій, а також з низьким рівнем побутової адаптації.

Синдром ігнорування має негативний вплив на рівні побутової адаптації у пацієнтів 3 невеликим руховим дефріцитом (при більш виражених рухових порушеннях ступінь впливу даного синдрому на здатність до самообслуговування мінімальний). Серед осіб з неглектом достовірно вищий рівень поширеності депресії порівняно 3 особами, у яких не порушено просторове сприйняття [3].

Розглядаючи пацієнтів з ураженням головного мозку, а саме правої півкулі, поширеність неглекту становить від 13 до 82 \%. Відновлення 
синдрому ігнорування становить від 60 до $90 \%$ протягом 3-12 міс. після інсульту. 3 цих спостережень можна зробити висновок, що більшість пацієнтів з пошкодженням правої півкулі мають неглект у гострій фразі, і що багато хто з них мають ремісію дефріциту в хронічній фазі [17].

Пацієнти 3 помірним та важким неглектом показують декілька видів поведінки, що характерні для даного синдрому. Вони спрямовують свій погляд у бік неураженої сторони, і не будуть звертати увагу на подразники, що надходять 3 ураженої сторони. Крім того, вони досить часто їдять з одного боку тарілки, чи приділяють ураженій стороні менше уваги, таким чином, що голять лише пів обличчя (такий вид неглекту називають особистісним). Зазвичай, для терапевта неглект досить очевидне явище під час проведення реабілітації. Наприклад, користувач інвалідного візка може неодноразово наштовхуватися на стіни та предмети, що розташовані на ігнорованій стороні, чи може пропускати слова при читанні тексту з одного боку сторінки, або неправильно розпізнавати одну сторону окремих слів. Деякі пацієнти, як правило, не використовують свою уражену кінцівку, навіть якщо немає слабкості або сенсорної втрати: це називається руховим неглектом.

Існує декілька стандартних тестів для виявлення неглекту. Традиційно клініцисти використовують перо-паперові завдання для легкого використання. До них відносяться тестування, такі, як тест викреслювання зірок (Star Concellation Test); тест поділу ліній навпіл (Line Bisection Test) та ін. Ці тести використовуються найчастіше [15].

Тест на викреслювання зірок - інструмент скринінгу, розроблений для виявлення наявності синдрому неглекту у пацієнтів з інсультом.

У цьому тесті $€ 52$ великі зірки, 13 букв та 10 коротких слів, 56 маленьких зірок (рис. 1). Пацієнт повинен викреслити олівцем усі маленькі зірки на аркуші форматом А4. Для демонстрації використовують дві маленькі зірки в центрі. Сторінка розміщена по середній лінії перед пацієнтом.

Максимальний бал, який можна досягти на тестуванні, становить 54 бали (56 маленьких зірок у загальному вигляді мінус 2, що використовуються для демонстрації). Результат <44 показує наявність неглекту. Індекс латеральності, або коефріцієнт зірки, можна розрахувати за співвідношенням зірочок, викреслених з лівого боку аркуша, до загальної кількості відмічених зірок, бали від 0 до 0,46 вказують наявність неглекту у лівій півкулі. Бали від 0,54 до 1 - у правій півкулі [7].

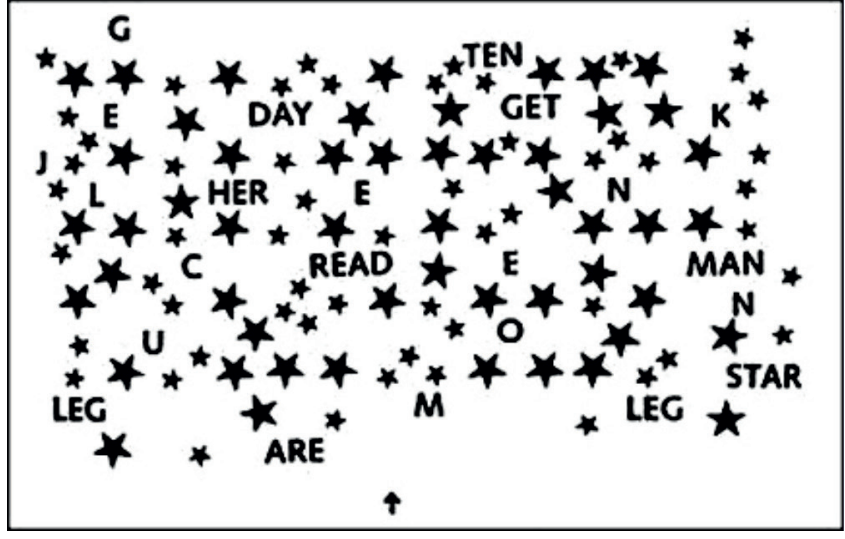

Рисунок 1 - Тест на викреслювання зірок

Тест поділу ліній навпіл. Тест оцінюють шляхом вимірювання відхилення бісекції від справжнього центру лінії. Відхилення понад 6 мм від середини вказує на наявність неглекту. Пропускання двох або більше рядків на одній половині аркуша вказує на наявність неглекту.

Наявність або відсутність неглекту базується на кількості ліній, залишених неперекресленими на кожній стороні тестового аркуша. Якщо будьякі лінії залишаються непереклесленими, і понад $70 \%$ неперекреслених ліній знаходяться на стороні з моторним дефріцитом, вказується наявність неглекту. Він може бути кількісно визначений як відсоток ліній, що залишилися неперекресленими [9].

Монреальська шкала оцінювання когнітивних функцій (МоСА) була розроблена як інструмент швидкого скринінгу для виявлення помірної когнітивної дисфрункції. За допомогою шкали можна оцінити такі когнітивні аспекти, як увага й концентрація, виконавчі фрункції, пам'ять, мовлення, зорово-конструктивні навички, абстрактне мислення, рахунок і орієнтація [13].

Сумарна кількість балів: сума балів за кожне завдання підраховується на правому боці аркуша. Якщо обстежуваний отримав освіту 12 років або менше, то потрібно додати один бал. Максимальний результат за цим тестом - 30 балів. Остаточна сума у 26 балів і більше розглядається як норма. Оскільки МоСА сильно залежить від мовлення, то краще не застосовувати ії до пацієнтів з афразією.

На додаток до цих тестів на неглект існує декілька тестів, які стосуються різних видів поведінки. Наприклад, особистісний неглект може бути оцінений через побутові завдання, в яких пацієнта просять розчісувати волосся чи здійснювати інші види догляду за тілом. Пропонують пацієнтам назвати предмети, які знаходяться в кімнаті навколо них. Пацієнти з неглектом у 
ТАБЛИЦЯ 1 - Результати дослідження за тестом викреслювання зірок

\begin{tabular}{|l|c|c|}
\hline \multicolumn{1}{|c|}{ Зірочки } & Ме $(25 ; \mathbf{7 5 )}$ & Норма \\
\hline Маленькі & $19(14 ; 22)$ & $54(56-2)$ \\
\hline Великі & $16(12 ; 19)$ & 52 \\
\hline Всього & $35(26 ; 41)$ & 106 \\
\hline
\end{tabular}

свою чергу, називають предмети лише з правої сторони [17].

Ступінь неглекту певним пацієнтом може варіюватись $[14,11]$ протягом доби. Це залежить від ступеня загального збудження, яке притаманне пацієнтам 3 правопівкульним інсультом головного мозку [5], тому дослідження проводили зранку, через годину після прийому їжі.

Фізичну терапію та ерготерапію починали 3 діагностики та оцінки. Використовували алгоритм діагностики «SOAP»: $\mathbf{S}$ - subjective (анамнез); 0 - objective (з допомогою клінічних тестів терапевт може підтвердити або виключити гіпотезу, яка виникла після суб'єктивної оцінки); А - assessment (аналіз даних суб'єктивної й об'єктивної оцінки для визначення діагнозу); P plan (план і цілі терапії).

Після збору анамнезу та контент-аналізу медичних карток для дослідження було обрано тест на викреслювання зірок (табл. 1). Дослідження показало низькі результати на знаходження та викреслювання маленьких зірочок - 19 (14;22) Ме (25; 75) балів при нормі 54 бали та 16 (12;19) балів на знаходження та викреслювання великих зірочок, при нормі 52 бали. Виконання становило 33,0 \% від норми, що свідчить про наявність неглекту.

Індекс латеральності становив 0,71, що вказує на наявність неглекту у правій півкулі.

Результати за тестом поділ ліній навпіл також свідчили про наявність неглекту. Так, пацієнти перекреслили $18(12 ; 25)$ Мe $(25 ; 75)$ ліній, що становило 46,1 \% від норми.

ТАБЛИЦЯ 2 - Результати дослідження по шкалі «Монреальська шкала оцінювання когнітивних функцій» (МоСА)

\begin{tabular}{|l|c|c|}
\hline \multicolumn{1}{|c|}{ Показники } & Ме $(25 ; 75)$ & Норма \\
\hline $\begin{array}{l}\text { Зорово-конструктивні виконавчі } \\
\text { навички }\end{array}$ & $1(1 ; 2)$ & 5 \\
\hline Назви речей та предметів & $1(0 ; 1)$ & 3 \\
\hline Пам'ять & $3(2 ; 4)$ & 5 \\
\hline Увага & $3(1 ; 4)$ & 6 \\
\hline Мовлення & $2(2 ; 3)$ & 3 \\
\hline Абстракція & $0(0 ; 1)$ & 2 \\
\hline Орієнтація & $3(3 ; 4)$ & 6 \\
\hline Всього & $13(9 ; 18)$ & 30 \\
\hline
\end{tabular}

За даними таблиці 2 видно, що внаслідок неглекту за тестом МоСА у пацієнтів було виявлено проблеми 3 зорово-конструктивними виконавчими навичками - $1(1 ; 2)$ Me $(25 ; 75)$ бал. Усі пацієнти не змогли правильно виконати завдання - намалювати куб та годинник.

Також пацієнти мали низькі бали в підпунктах «пам'ять» $-3(2 ; 4)$ Ме $(25 ; 75)$ бали, «увага» -3 $(1 ; 4)$ бали, та «оріентація» $3(3 ; 4)$ бали. У пункті «абстракція» пацієнти отримали $0(0 ; 1)$ Me $(25$; 75) балів.

Результати визначення важкості неглекту мають виявити цілі фрізичної терапії та ерготерапії осіб, які перенесли інсульт. Але в той же час ліквідація неглекту не може бути метою терапії. Основна мета - це, за можливості, незалежне функціонування пацієнта. Короткотривалі цілі спрямовані на відновлення рухових функцій, покращення пам'яті, планування та абстрактне мислення. Насамперед, проводили навчання опікунів пацієнта речей, які допомогли б йому у виконанні повсякденних справ, таких, як одягання, приймання душу, їжі, користування телефоном. Використовували стратегії та сигнали з яскравими плямами. Особливість навчання пацієнта з неглектом полягає в розміщенні червоних ліній-маячків посередині одягу та інших предметів для усвідомлення пацієнтом, де саме середина. Також використовувалась стратегія «зникаючих підказок», яка полягала у поступовому ускладненні завдань, стратегія безпомилкового навчання та подвійних завдань. Побудова занять залежала від запитів пацієнта.

Висновки. Синдром неглекту - це порушення сприйняття простору і схеми свого тіла, виражений в ігноруванні половини тіла і/чи простору з боку, протилежного ураженій півкулі головного мозку, а також інформації, що надходить з цього боку. Результати за тестами на викреслювання зірок становили 33 \%, а поділ ліній навпіл $46,1 \%$ від норми. Внаслідок неглекту у пацієнтів за тестом МоСА було виявлено проблеми із зорово-конструктивними виконавчими навичками, пам'яттю, увагою, абстракцією та орієнтацією. Загальний бал становив $13(9 ; 18)$ з 30 можливих. Результати визначення важкості неглекту мають виявити цілі фрізичної терапії та ерготерапії осіб, які перенесли інсульт.

Перспективи подальших досліджень вбачаємо у розробці та впровадженні програми фрізичної терапії та ерготерапії, а також у визначенні доцільності застосування запропонованих втручань у осіб з правопівкульним ішемічним інсультом, ускладненим неглектом. 


\section{Література}

1. Гусев ЕИ, Боголепова АН. Когнитивные нарушения при цереброваскулярных заболеваниях [Cognitive impairment in cerebrovascular disease]. МЕДпрессинформ, 2013; 160 c.

2. Поліщук Мє. Про заходи щодо попередження смертності та інвалідності від серцево-судинних та судинномозкових захворювань [On measures to prevent mortality and disability from cardiovascular and vascular diseases]. Нейрон ревю. 2003; 5: 1-3.

3. Шевченко ЛА. Синдром игнорирования при полушарном инсульте. [Hemispheric ignore syndrome]. Журнал неврологии и психиатрии им. С. С. Корсакова. Спецвыпуски 112.12 (2012): 40-2.

4. Abe H, Kondo T, Oouchida Y, et al. Prevalence and length of recovery of pusher syndrome based on cerebral hemispheric lesion side in patients with acute stroke. Stroke. 2012; 43(9): 165-6.

5. Bowen A, Bowen A, Hazelton C, Pollock A, at al. Cognitive rehabilitation for spatial neglect following stroke. Cochrane Database Syst Rev (Online). 2013/07/01. VL7. https://doi. org/10.1002/14651858.CD003586.pub3

6. Buxbaum LJ, Hallett M, Wheaton L. Treatment of Limb Apraxia: moving forward to improved action. Phys Med Rehabil. 2008; 87: 149-161.

7. Dong Y, Sharma V, Chan B. The Montreal Cognitive Assessment (MoCA) is superior to the Mini-Mental State Examination (MMSE) for the detection of vascular cognitive impairment after acute stroke. Journal of Neurological Sciences. 2010; 51.

8. Flomin YuV, et al. Predictors of dependency in post-discharge activities of daily living among stroke in-patients managed in a comprehensive stroke unit. International neurological journal. 2019; 5.107: 52-61.

9. Fullerton KJ, Mcsherry D, Stout RW. Albert's test: a neglected test of perceptual neglect. The Lancet. 1986; 327.8478: 430-2.

yura.dido.1994@gmail.com
10. GBD 2016 Stroke Collaborators. Global, regional, and national burden of stroke, 1990-2016: a systematic analysis for the Global Burden of Disease Study 2016. Lancet Neurol. 2019 May; 18(5): 439-458. https://doi.org/10.1016/S14744422(19)30034-1.

11. Jehkonen $M$, Laihosalo $M$, Koivisto A. Fluctuation in spontaneous recovery of left visual neglect: a 1-year follow-up. Eur Neurol. 2007; 58: 210-14.

12. Kanai M, at al. Promoting physical activity in hospitalized patients with mild ischemic stroke: a pilot study. Topics in stroke rehabilitation. 2017; 24.4: 256-261.

13. Linator D, Heinemann Y, Wright B. The FIM estimates that a person can perform, not what that person can do under certain circumstances. Arch Phys Med Rehabil. 1994; 75: 127132.

14. Machner B, Mah Y, Gorgoraptis N. How reliable is repeated testing for hemispatial neglect? Implications for clinical follow-up and treatment trials. J Neurol Neurosurg Psychiatry. 2012; 83: 1032-4.

15. McIntosh R, Brodie E, Beschin N. Improving the clinical diagnosis of personal neglect: a reformulated comb and razor test. Cortex. 2000; 36: 289-92.

16. Norrving B, Barrick J, Davalos A, Dichgans, at al. Action Plan for Stroke in Europe 018-2030. (C) 2018 European Stroke Organisation 2018. Eur Stroke J. 2018 Dec; 3(4): 309-336. Published online 2018 Oct 29. doi: 10.1177/2396987318808719

17. Stone B, Wilson A. Wroot The assessment of visuospatial neglect after acute stroke. Neurol Neurosurg Psychiatry. 1991; 4: 345-50.

18. Worid Health Organizadon. Worid Report on Disability 2011.Geneva: World Health Organization, 2011. Rehabilitation. www.ncbi.nlm.nih.gov/books/NBK30 4081/ (accessed 19 April 2018). 